\title{
Open
}

\section{Do Typhoons Cause Turbulence in Property-Liability Insurers' Stock Prices?}

\section{Takashi Yamasaki}

Graduate School of Business Administration, Kobe University, 2-1 Rokkodai-cho, Nada-ku, Kobe, Hyogo 657-8501, Japan.

E-mail: yamasaki@kobe-u.ac.jp

The aim of this paper is to clarify how natural disasters influence the stock prices of propertyliability insurance companies. Examining a series of typhoons that made landfall in Japan, this paper shows that the stock prices of property-liability insurers, on average, increase around typhoon landfalls. However, cross-sectional results indicate that specific insurer or typhoon characteristics can temper the increase. First, a property-liability insurer's stock price reacts more positively around typhoons of greater scale and more negatively around typhoons with longer intervals from the previous typhoon landfall, with longer times to landfall, or that cause more serious residential damage. Second, a property-liability insurer's stock price reacts according to its profitability or business structure. In addition, insurers with a larger capital buffer or of greater financial soundness are evaluated relatively higher around typhoon landfall since the deregulation of the insurance industry.

The Geneva Papers (2016) 41, 432-454. doi:10.1057/gpp.2015.29

Keywords: property-liability insurer; stock performance; natural disaster; typhoon; insurance regulation

Article submitted 27 March 2015; accepted 09 September 2015; published online 11 November 2015

The online version of this article is available Open Access

\section{Introduction}

Natural disasters, such as earthquakes, hurricanes, typhoons and tsunamis, cause serious economic loss. Property-liability insurers contribute to stabilising social conditions by assuming part of the risk of catastrophe. This implies, however, that they must pay tremendous insurance claims after a catastrophe. For example, in the Great East Japan earthquake (GEJE) off the coast of Sanriku in 2011, the total amount of earthquake insurance payouts reached US $\$ 15.4 \mathrm{bn}$ for 780,000 cases. ${ }^{1}$

Since the 1990s, there has been considerable research concerning the effect of catastrophes on the stock prices of insurers. Nonetheless, whether a catastrophe has a negative impact on the stock prices of property-liability insurance companies is still debatable. Previous studies have focused on the effects of single catastrophes, such as the

\footnotetext{
${ }^{1}$ This information is from the General Insurance Association of Japan's chair's statement on 21 June 2012. The figures are based on $¥ 1.23$ tn converted at that time’s exchange rate of $¥ 80$ to the U.S. dollar.
} 
Loma Prieta earthquake or Hurricane Andrew, on insurer firm value, making it difficult to determine the characteristics of natural disasters or property-liability insurers and their impacts on stock prices. For example, Takao et al. ${ }^{2}$ investigate the effect of the GEJE on the firm value of Japanese property-liability insurance companies and find that stock prices decreased immediately after the earthquake. The authors focus only on the GEJE and do not state that natural disasters generally impair the firm value of insurance companies. Unlike such previous studies, the unique point of this study is to investigate the factors that drive market reactions to property-liability insurer stocks around natural disasters by using over 900 observations obtained from a series of typhoon landfalls in Japan.

Typhoons are selected as a representative of natural disasters for the following reasons. First, because of geographical conditions, Japan is at high risk from natural hazards such as typhoons, earthquakes and tsunamis. Typhoon damage is a particularly serious problem and therefore has great social and economic impact. The approach of typhoons is of public concern and typhoon warnings are frequently reported in the media, with typhoons making landfall covered by the news.

The second reason is the number of observations produced by typhoons. Typhoons make landfall in Japan nearly every year, totalling about 100 in the last three decades. Since this study requires many observations, typhoons allow for a sufficient number.

The final reason is the large scale of the Japanese stock and insurance markets. Sufficient time-series data can therefore be accessed, since the Japanese stock market has been one of the largest in the world for many decades. In addition, since Japan has the second largest insurance market after the United States, ${ }^{3}$ it is suitable for testing this study's hypotheses.

The remainder of this paper is organised as follows: The next section presents the characteristics of typhoons and compares them with those of other natural disasters, such as hurricanes and earthquakes. The subsequent section reviews the literature about the impact of catastrophes on the stock prices of insurers and discusses areas for further research. The latter section develops the hypotheses and discusses the sample data and methodologies used. The penultimate section presents the empirical results and the final section the conclusion.

\section{Overview of typhoons}

\section{Classification of tropical cyclones}

The World Meteorological Organization (WMO) defines a low-pressure area in the torrid zone (also called a tropical cyclone) that develops in the north-western part of the Pacific Ocean or the South China Sea as a tropical depression if it has maximum 10-min sustained winds of 33 knots $(17.1 \mathrm{~m} / \mathrm{s})$ or less near the centre, as a tropical storm if the winds are 34-47 knots $(17.2-24.4 \mathrm{~m} / \mathrm{s})$ near the centre, as a severe tropical storm if the winds are 48-63 knots $(24.5-32.6 \mathrm{~m} / \mathrm{s})$ near the centre, and as a typhoon if the winds are 64 knots $(32.7 \mathrm{~m} / \mathrm{s})$ or more near the centre. On the other hand, the Japan Meteorological Agency (JMA) lumps the terms tropical storm, severe tropical storm and typhoon together under the Japanese term taifü. The JMA also classifies a typhoon with maximum 10-min sustained

\footnotetext{
2 Takao et al. (2013).

${ }^{3}$ Sigma (2014).
} 
Table 1 Classification of tropical cyclones

\begin{tabular}{|c|c|c|c|}
\hline $\begin{array}{c}\text { Maximum sustained winds } \\
\text { (knots) }\end{array}$ & WMO criteria & \multicolumn{2}{|c|}{$J M A$ criteria } \\
\hline-33 & Tropical depression (TD) & \multicolumn{2}{|c|}{ Tropical depression (TD) } \\
\hline $34-47$ & Tropical storm (TS) & \multirow{5}{*}{ Typhoon (TY) } & \multirow{2}{*}{ (Unspecified) } \\
\hline $48-63$ & Severe tropical storm (STS) & & \\
\hline $64-84$ & \multirow{3}{*}{ Typhoon (TY) } & & Strong TY \\
\hline $85-104$ & & & Very strong TY \\
\hline $105-$ & & & Violent TY \\
\hline
\end{tabular}

winds of 64-84 knots $(32.7-43.7 \mathrm{~m} / \mathrm{s})$ as a strong typhoon, one with winds of 85-104 knots $(43.8-54.0 \mathrm{~m} / \mathrm{s})$ as a very strong typhoon, and one with winds of $105 \mathrm{knots}(54.1 \mathrm{~m} / \mathrm{s})$ or more as a violent typhoon. ${ }^{4}$ Table 1 shows the different classifications of tropical cyclones according to the WMO and JMA.

This paper includes tropical storms, severe tropical storms and typhoons in the sample of typhoons, based on the JMA criteria. Since these are all lumped together as taif $\bar{u}$ in Japan, including them all in the sample facilitates examination of the impact on the stock prices of property-liability insurers in the Japanese stock market.

\section{Typhoon landfalls in Japan}

The JMA defines a typhoon as having made landfall in Japan when its centre has reached the coastline of Hokkaido, Honshu (the main island), Shikoku or Kyushu. Table 2 shows the number of typhoons that made landfall in Japan each month from 1979 to 2013, for a total of 93. As shown, about 90 per cent of the sample made landfall in Japan between July and October. The annual mean number of typhoon landfalls is about 2.7.

Figure 1 shows the number of typhoons in the sample that passed through each region. Typhoons passed through all the regions almost evenly, implying that all of Japan is equally under the potential influence of typhoon damage.

\section{Typhoon damage}

Typhoons cause damage by wind, flood, storm surge and ocean waves and hurt the earnings of Japanese property-liability insurers. For example, during 2004, 10 typhoons made landfall in Japan, an all-time high since observations began. These typhoons caused serious damage throughout Japan, with total insurance claim payments for Japanese property-liability insurers of $¥ 763.9 \mathrm{bn}, 13.2$ times more than in the previous year.

\footnotetext{
${ }^{4}$ The JMA used to classify tropical storms as weak typhoons and severe tropical storms as medium typhoons but no longer uses that classification.
} 
Table 2 Monthly distribution of typhoon landfalls in Japan, 1979-2013

\begin{tabular}{|c|c|c|c|c|c|c|c|c|c|c|c|c|c|}
\hline & Jan. & Feb. & Mar. & Apr. & May & Jun. & Jul. & Aug. & Sep. & Oct. & Nov. & Dec. & Total \\
\hline 1979 & & & & & & & & & 2 & 1 & & & 3 \\
\hline 1980 & & & & & & & & & 1 & & & & 1 \\
\hline 1981 & & & & & & 1 & 1 & 1 & & & & & 3 \\
\hline 1982 & & & & & & & & 2 & 2 & & & & 4 \\
\hline 1983 & & & & & & & & 1 & 1 & & & & 2 \\
\hline 1984 & & & & & & & & & & & & & 0 \\
\hline 1985 & & & & & & 1 & & 2 & & & & & 3 \\
\hline 1986 & & & & & & & & & & & & & 0 \\
\hline 1987 & & & & & & & & & & 1 & & & 1 \\
\hline 1988 & & & & & & & & 2 & & & & & 2 \\
\hline 1989 & & & & & & 1 & 1 & 2 & 1 & & & & 5 \\
\hline 1990 & & & & & & & & 2 & 2 & 1 & 1 & & 6 \\
\hline 1991 & & & & & & & & 1 & 2 & & & & 3 \\
\hline 1992 & & & & & & & & 3 & & & & & 3 \\
\hline 1993 & & & & & & & 3 & 1 & 2 & & & & 6 \\
\hline 1994 & & & & & & & 1 & 1 & 1 & & & & 3 \\
\hline 1995 & & & & & & & & & 1 & & & & 1 \\
\hline 1996 & & & & & & & 1 & 1 & & & & & 2 \\
\hline 1997 & & & & & & 2 & 1 & & 1 & & & & 4 \\
\hline 1998 & & & & & & & & & 3 & 1 & & & 4 \\
\hline 1999 & & & & & & & & & 2 & & & & 2 \\
\hline 2000 & & & & & & & & & & & & & 0 \\
\hline 2001 & & & & & & & & 1 & 1 & & & & 2 \\
\hline 2002 & & & & & & & 2 & & & 1 & & & 3 \\
\hline 2003 & & & & & 1 & & & 1 & & & & & 2 \\
\hline 2004 & & & & & & 2 & & 4 & 2 & 2 & & & 10 \\
\hline 2005 & & & & & & & 1 & 1 & 1 & & & & 3 \\
\hline 2006 & & & & & & & & 1 & 1 & & & & 2 \\
\hline 2007 & & & & & & & 1 & 1 & 1 & & & & 3 \\
\hline 2008 & & & & & & & & & & & & & 0 \\
\hline 2009 & & & & & & & & & & 1 & & & 1 \\
\hline 2010 & & & & & & & & 1 & 1 & & & & 2 \\
\hline 2011 & & & & & & & 1 & & 2 & & & & 3 \\
\hline 2012 & & & & & & 1 & & & & 1 & & & 2 \\
\hline 2013 & & & & & & & & & 2 & & & & 2 \\
\hline Total & 0 & 0 & 0 & 0 & 1 & 8 & 13 & 29 & 32 & 9 & 1 & 0 & 93 \\
\hline
\end{tabular}

Table 3 shows the 10 largest claims paid for natural disasters in Japan, 8 of which were due to typhoons. In addition, the table shows that fire and miscellaneous insurance claim payments account for more than 90 per cent of total typhoon damage claims.

\section{Comparison to hurricanes and earthquakes}

A hurricane is defined as a tropical cyclone with maximum 10-min sustained winds of 64 knots or more near the centre that develops in the north-eastern part of the Pacific Ocean, the northern part of the Atlantic Ocean, the Caribbean Sea or the Gulf of Mexico. 


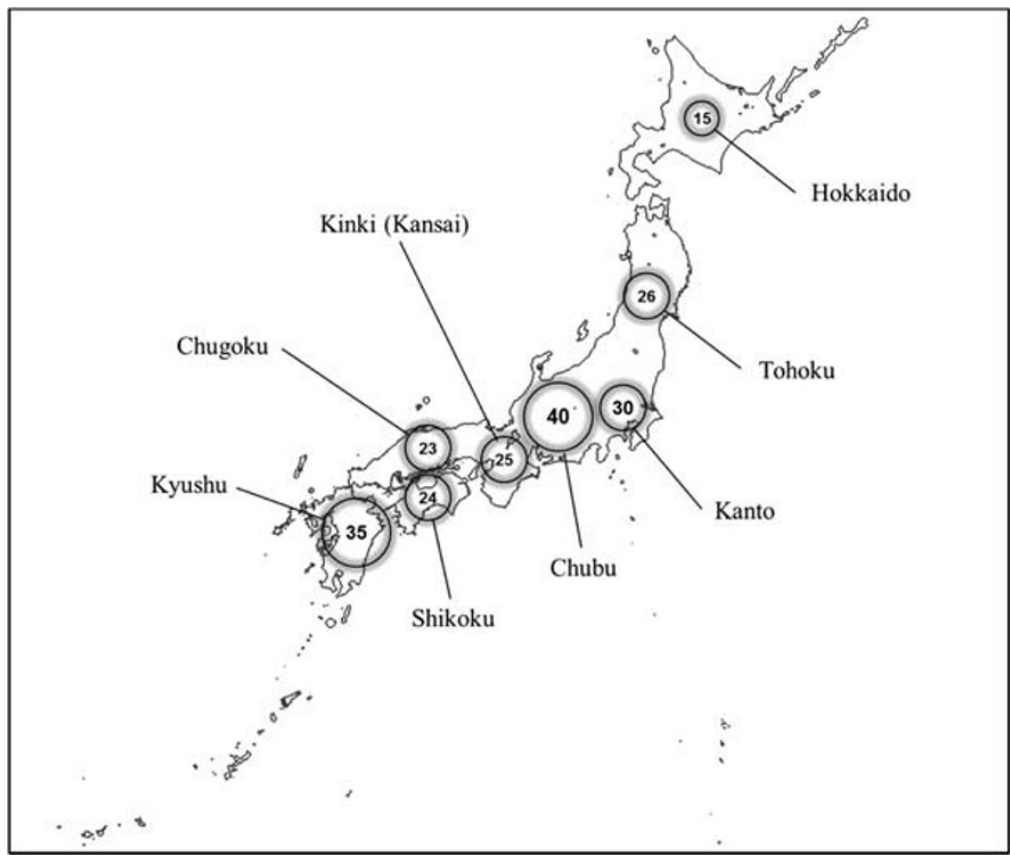

Figure 1. Geographical distribution of typhoons that passed through Japan from 1979 to 2013.

In other words, hurricanes have the same intensity as typhoons, based on the WMO criteria. Although, in the United States, hurricanes have been concentrated on the East Coast and coastal areas such as Texas, Louisiana, Mississippi, Alabama and Florida, typhoons in Japan can cause damage nationwide.

Japan is also at high risk from earthquakes and it is here that the earthquake insurance system developed. Household fire insurance in Japan covers losses caused by fire, lightning, typhoons, flooding and so on, but not losses due to earthquakes, volcanic eruptions or tsunamis. To cover the perils of earthquakes and tsunamis, policyholders must purchase earthquake insurance on dwelling risks. The laws concerning earthquake insurance stipulate that Japan Earthquake Reinsurance, Japanese property-liability insurers and the government share these insurance liabilities. ${ }^{5}$

Regarding market reactions to stock prices around natural disasters, it is hard to predict the time, location and scale of earthquakes until right before they happen. On the other hand, the time, location, scale and landfall of typhoons are forecast to some extent a few days in advance. This implies a difference in the speed of response of the stock market between earthquakes and typhoon or hurricane landfalls.

\footnotetext{
${ }^{5}$ See Takao et al. (2013) for details.
} 
Table 3 Ten largest claims paid for natural disasters in Japan (in billions of yen)

\begin{tabular}{|c|c|c|c|c|c|c|c|c|}
\hline \multirow{2}{*}{\multicolumn{2}{|c|}{ Name of disaster }} & \multirow[b]{2}{*}{ Place } & \multirow[b]{2}{*}{ Date } & \multicolumn{5}{|c|}{ Claims paid } \\
\hline & & & & Earthquake & $\begin{array}{c}\text { Fire and } \\
\text { miscellaneous }\end{array}$ & Automobile & Marine & Total \\
\hline 1 & Great East Japan & Tohoku region & 11 Mar. 2011 & $1,257.9$ & - & - & - & $1,257.9$ \\
\hline 2 & Typhoon No.19 & Nationwide & 26-28 Sept. 1991 & - & 522.5 & 26.9 & 18.5 & 567.9 \\
\hline 3 & Typhoon No.18 & Nationwide & 4-8 Sept. 2004 & - & 356.4 & 25.9 & 5.1 & 387.4 \\
\hline 4 & Typhoon No.18 & $\begin{array}{l}\text { Kumamoto, } \\
\text { Yamaguchi, } \\
\text { Fukuoka, etc. }\end{array}$ & 21-25 Sept. 1999 & - & 284.7 & 21.2 & 8.8 & 314.7 \\
\hline 5 & Typhoon No.7 & Kinki & 22 Sept. 1998 & - & 151.4 & 6.1 & 2.4 & 160.0 \\
\hline 6 & Typhoon No.23 & $\begin{array}{l}\text { Western part of the } \\
\text { nation }\end{array}$ & 20 Oct. 2004 & - & 111.3 & 17.9 & 8.9 & 138.0 \\
\hline 7 & Typhoon No.13 & $\begin{array}{l}\text { Fukuoka, Saga, } \\
\text { Nagasaki, Miyazaki, } \\
\text { etc. }\end{array}$ & 15-20 Sept. 2006 & - & 116.1 & 14.7 & 1.2 & 132.0 \\
\hline 8 & Typhoon No.16 & Nationwide & 30-31 Aug. 2004 & - & 103.7 & 13.8 & 3.5 & 121.0 \\
\hline 9 & Typhoon No.15 & $\begin{array}{l}\text { Shizuoka, } \\
\text { Kanagawa, etc. }\end{array}$ & 15-22 Sept. 2011 & - & 100.4 & 10.0 & 1.9 & 112.3 \\
\hline 10 & Downpour, Sep.2000 & Aichi etc. & 10-12 Sept. 2000 & - & 44.7 & 54.5 & 3.9 & 103.0 \\
\hline
\end{tabular}

Source: General Insurance Association of Japan website, www.sonpo.or.jp.

\section{Do natural disasters affect the stock prices of property-liability insurers?}

Since the 1990s, there has been considerable research concerning the effect of natural disasters, especially earthquakes, on the firm value of insurance companies. Shelor et $_{\text {al. }}{ }^{6}$ find that the average abnormal stock returns of property-liability insurers were significantly positive following the Loma Prieta earthquake that struck California in 1989. Based on their results, the authors argue that insurers benefit from catastrophic events because of subsequent increased demand ("gaining from loss" hypothesis). Employing a different approach, Aiuppa et al. ${ }^{7}$ also find similar results, with the Loma Prieta earthquake having had a positive impact on the stock returns of non-life insurance companies.

Aiuppa and Krueger ${ }^{8}$ and Lamb and Kennedy ${ }^{9}$ investigate the impact of the 1994 Northridge earthquake in Los Angeles on the firm value of insurance companies. Lamb and Kennedy find that property-liability insurers experienced a significant positive reaction immediately after the Northridge earthquake. Aiuppa and Krueger, on the other hand, indicate that earthquake-exposed firms sustained their value and non-earthquake-exposed insurers declined in value immediately after the Northridge earthquake.

Yamori and Kobayashi ${ }^{10}$ investigate the stock market reactions of Japanese insurers following the 1995 Great Hanshin-Awaji earthquake and find significantly negative

\footnotetext{
${ }^{6}$ Shelor et al. (1992).

${ }^{7}$ Aiuppa et al. (1993).

${ }^{8}$ Aiuppa and Krueger (1995).

${ }^{9}$ Lamb and Kennedy (1997).

${ }^{10}$ Yamori and Kobayashi (2002).
} 
abnormal returns. Takao et al. ${ }^{2}$ investigate how the GEJE influenced Japanese insurance companies and find that the stock prices of insurers decreased immediately afterwards. They argue that the GEJE provided a negative signal and that the potential earthquake losses would be larger than the increase in expected insurance premiums due to increasing demand for coverage.

Regarding hurricanes, Lamb ${ }^{11}$ finds that, in 1992, Hurricane Andrew in southern Florida and Louisiana had a significant negative impact on the stock returns of hurricane-exposed insurers. Cagle ${ }^{12}$ investigates Hurricane Hugo in South Carolina in 1989 and finds similar results, the hurricane having had a negative impact on the stock returns of exposed insurers.

Blau et al. ${ }^{13}$ investigate short-selling activity around Hurricanes Katrina and Rita and find the following. First, abnormal short selling did not increase until two trading days after Katrina's landfall and short-selling activity was much more significant around Rita. Second, there was a substantial increase in short-selling activity in the trading days prior to Rita's landfall and relatively less short-selling activity afterwards. The authors conclude that there is little evidence to suggest that traders short insurance stocks with more potential exposure in the affected region more heavily than other insurance stocks in the days before landfall.

To conclude, previous studies focus on the effects of a single specific catastrophe on insurer firm value and therefore conduct cross-sectional regression analyses using only one or two independent variables due to the limited number of observations. In other words, the problem involves determining not only the characteristics of property-liability insurers that influence their stock performance around natural disasters, but also the characteristics and influence of the natural disasters themselves. In addition, while previous studies employ the market model as a measure of stock performance, this study also employs the Fama-French three-factor model, since it is a standard in event study analysis. ${ }^{14}$

\section{Research design}

\section{Hypothesis}

This paper investigates two opposing hypotheses. The first hypothesis is that the rapid depletion of surplus accounts following a natural disaster causes investors to discount property-liability insurer stocks. There are two possible causes: market value loss due to pure book value losses (i.e. the net present value of claims paid) and market value loss above the book value loss (i.e. due to the market's re-evaluation of either the underlying risk processes or firm profitability). Under this hypothesis, unexpectedly large insurance claims can result in lower net cash flows for insurers and reduce firm value.

${ }^{11}$ Lamb (1995).

12 Cagle (1996).

13 Blau et al. (2008).

${ }^{14}$ In current event studies, Carhart's four-factor model, which extends the Fama-French three-factor model by a momentum factor, is standard. However, this study employs the Fama-French three-factor model because momentum is not observed in the Japanese stock market. 
The second hypothesis is that insurers benefit from a natural disaster because of subsequent increased consumer and/or institutional demand, including increases in coverage and additional premium earnings. Under this hypothesis, the additional earnings from increased demand will more than offset any losses, so that insurers' stock prices rise around a natural disaster.

The question of which of the two opposing hypotheses is supported depends on which has more influence: unexpected insurance claims or additional earnings from increased demand. If the insurance claims from a natural disaster exceed investors' expectations of additional insurance demand, the property-liability insurer's stock price will decrease-and vice versa. It appears that this balance between losses and earnings differs according to natural disasters and insurers. Therefore, this paper examines which characteristics of natural disasters and property-liability insurers have a positive or negative impact on stock prices.

\section{Sample}

To examine the impact of a series of natural disasters on property-liability insurers, this paper investigates typhoons that made landfall in Japan from 1979 to $2013 .{ }^{15}$ As discussed in the section "Overview of typhoons", the sample includes tropical storms and severe tropical storms. The meteorological data is available from Kisyonenkan, published yearly by the Japan Meteorological Business Support Center. A total of 93 typhoons made landfall in Japan over this period (see Table 2).

The sample means of the highest atmospheric pressures (in hectopascals), maximum wind speeds (in metres per second) and maximum rainfall (in millimetres per hour) are $969.9 \mathrm{hPa}$, $31.2 \mathrm{~m} / \mathrm{s}$ and $385.4 \mathrm{~mm}$, respectively. It takes a typhoon 5.6 days, on average, from birth to landfall in Japan. After landfall, a typhoon ends in 27.7 hours, on average. Of the sample, three pairs of typhoons-Typhoon Nos. 13 and 14 in 1985, Typhoon Nos. 11 and 13 in 1988, and Typhoon Nos. 7 and 8 in 1998-made landfall the same day.

To test market reactions to insurers around typhoon landfalls, I examine the stock returns of Japanese property-liability insurers traded on the Tokyo Stock Exchange (TSE). From 1 April 1979 to 31 March 2014, 17 property-liability domestic insurers were listed in the first section of the TSE. ${ }^{16}$ Table 4 shows the property-liability insurers in the sample. ${ }^{17}$ Because of the insurance market's maturity, Japanese property-liability insurers have restructured through a series of alliances and mergers since 2000. Today, the Japanese property-liability insurance industry is dominated by three "mega" insurance groups: Tokio Marine Holdings, MS\&AD Insurance Group Holdings and Sompo Japan Nipponkoa Holdings. Table 4 also shows the test periods in which each insurer is included.

This paper analyses only property-liability insurers and does not target life insurers, because most large Japanese life insurers were mutual companies and were not listed in the

15 The reason why the test period starts in 1979 is that the stock price data is available only since August 1977 and the estimation period of 200 trading days before a typhoon landfall is necessary, as discussed later.

${ }^{16}$ During this period, Taiyo Fire \& Marine Insurance was traded in the over-the-counter market but it is excluded from the sample because its stock was hardly traded.

${ }^{17}$ The only foreign property-liability insurer listed in the TSE during the period was American International Group (AIG). This paper does not include AIG in the sample because it is a global insurance company and the impact of local information on its stock price is relatively small. 
Table 4 Japanese property-liability insurers in the sample

\begin{tabular}{clcr}
\hline No. & \multicolumn{1}{c}{ Name } & Listing exchange & Test period \\
\hline 1 & Tokio Marine \& Fire Insurance & TSE 1st & $1979-2001$ \\
2 & Mitsui Sumitomo Insurance & TSE 1st & $1979-2007$ \\
3 & Sumitomo Marine \& Fire Insurance & TSE 1st & $1979-2001$ \\
4 & Nipponkoa Insurance & TSE 1st & $1979-2009$ \\
5 & Sompo Japan Insurance & TSE 1st & $1979-2009$ \\
6 & Nissan Fire \& Marine Insurance & TSE 1st & $1979-2001$ \\
7 & Nisshin Fire \& Marine Insurance & TSE 1st & $1979-2006$ \\
8 & Chiyoda Fire \& Marine Insurance & TSE 1st & $1979-2000$ \\
9 & Nissay Dowa General Insurance & TSE 1st & $1979-2009$ \\
10 & Nichido Fire \& Marine Insurance & TSE 1st & $1979-2001$ \\
11 & Aioi Nissay Dowa Insurance & TSE 1st & $1979-2009$ \\
12 & Koa Fire \& Marine Insurance & TSE 1st & $1979-2000$ \\
13 & Fuji Fire \& Marine Insurance & TSE 1st & $1979-2011$ \\
14 & Taisei Fire \& Marine Insurance & TSE 1st & $1987-2001$ \\
15 & Tokio Marine Holdings & TSE 1st & $2002-2013$ \\
16 & MS \& AD Insurance Group Holdings & TSE 1st & $2008-2013$ \\
17 & Sompo Japan Nipponkoa Holdings & TSE 1st & $2010-2013$ \\
\hline
\end{tabular}

stock market during the test period. ${ }^{18}$ Furthermore, compared with earthquakes, human damage suffered from typhoons was not as serious over the test period, ${ }^{19}$ so that life insurers do not seem as affected by typhoons as property-liability insurers are.

In addition, stock price data, financial data and credit rating data are required for the analysis. Stock price data was acquired from the Portfolio Master Database, financial data was acquired from the Nikkei Economic Electronic Database Systems database and annual special issues of the Statistics of Japanese Non-Life Insurance Business, and credit rating data was acquired from Bloomberg.

\section{Methodology}

\section{Event study analysis}

To examine the proposed hypotheses, I conduct an event study analysis to assess the market reactions to insurer stocks around typhoon landfalls. An event's economic impact is measured as the difference (i.e. abnormal return) between the actual return on the security experiencing the event and the "normal" return (i.e. the expected return the security would have achieved had the event not happened). For each sample security $i$, the abnormal return for time period $t$ relative to the event (let $t=0$ be the event date) can be defined as

$$
A R_{i t}=R_{i t}-E\left(R_{i t}\right)
$$

\footnotetext{
${ }^{18}$ During the test period, only four Japanese life insurance companies were listed in the stock market: Daido Life, listed in 2002, Taiyo Life, listed in 2003, Dai-ichi Life, listed in 2010, and Lifenet, listed in 2012. Daido Life and Taiyo Life set up a joint holding company (T\&D Holdings) to integrate their business and delisted in 2004.

${ }^{19}$ For example, the GEJE and the earthquake-triggered tsunami in 2011 left over 15,000 people dead, whereas the highest number of fatalities and missing persons from typhoons over the test period was 95, in Typhoon No. 10 of 1982.
} 
where $A R_{i t}$ is the abnormal return, $R_{i t}$ is the actual (dividend-adjusted) return and $E\left(R_{i t}\right)$ is the expected return. Then, this study examines whether the cross-sectional distribution of returns at the time of the event is abnormal. In most event studies, the null hypothesis to be tested is whether the mean abnormal return at time $t$ is equal to zero. Furthermore, it is also interesting to examine whether the mean abnormal returns for periods around the event are equal to zero. To estimate the performance over any multi-period interval, the cumulative abnormal return (CAR), measured by the sum of abnormal returns over the period of interest, is generally used.

A model of normal returns must be specified to measure abnormal returns. Event studies generally use the market model. Using this approach, the expected return for any given insurer can be defined as

$$
E\left(R_{i t}\right)=\alpha_{i}+\beta_{i}^{M K T} R_{m t}+\varepsilon_{i t},
$$

where $R_{m t}$ is the market return and the coefficient $\beta_{i}^{M K T}$ is the market beta and represents the sensitivity of security $i$ 's return to the whole market's return.

Since the market beta has very little explanatory power, many event studies employ the Fama-French three-factor model. This model adds a size factor and a book-to-market factor to the capital asset pricing $\operatorname{model}^{20}$ :

$$
E\left(R_{i t}\right)-R_{f t}=\alpha_{i}+\beta_{i}^{M K T}\left(R_{m t}-R_{f t}\right)+\beta_{i}^{S M B} S M B_{t}+\beta_{i}^{H M L} H M L_{t}+\varepsilon_{i t},
$$

where $R_{f t}$ is the risk-free rate on day $t, S M B_{t}$ (small minus big) is the average return on three small portfolios minus the average return on three big portfolios on day $t$, and $H M L_{t}$ (high minus low) is the average return on two value portfolios minus the average return on two growth portfolios on day $t$.

This paper adopts both the standard market model (Eq. (2)) and the Fama-French threefactor model (Eq. (3)) in the event study methodology, where the returns of the underlying securities are assumed to be jointly multivariate normal and independently and identically distributed through time. ${ }^{21}$

The estimation period is 200 trading days, dating back from 21 trading days before each typhoon landfall. The abnormal return of the sample for the event window is calculated as

$$
\begin{gathered}
A R_{i \tau}=R_{i \tau}-\left(\hat{\alpha}_{i}+\hat{\beta}_{i}^{M K T} R_{m \tau}\right), \\
A R_{i \tau}=R_{i \tau}-\left(\hat{\alpha}_{i}+\hat{\beta}_{i}^{M K T} R_{m \tau}+\hat{\beta}_{i}^{S M B} S M B_{\tau}+\hat{\beta}_{i}^{H M L} H M L_{\tau}\right) .
\end{gathered}
$$

The event period comprises 26 trading days, from 5 trading days before through 20 trading days after each typhoon landfall. If a typhoon made landfall in Japan after 3:00 p.m., when the Japanese stock market closes, the typhoon landfall is assigned to the next trading day.

I examine the market reactions to firms belonging to the same insurance industry. I adjust the estimated variance in returns by the contemporaneous cross-sectional variance

\footnotetext{
${ }^{20}$ Fama and French (1993) argue that the size factor (SMB) and book-to-market factor (HML) reflect financial distress risk.

${ }^{21}$ I acquired the market, SMB and HML return data from Kubota and Takehara's Fama-French benchmark factors in the Portfolio Master Database.
} 
of the sample, applying the standardised cross-sectional procedure developed by Boehmer et al. ${ }^{22}$

First, for any given insurer, I calculate the standardised abnormal returns (SAR) by dividing the abnormal returns calculated using Eqs. (2) and (3) by the standard error for each, respectively. Next, I compute the $z$-statistics as

$$
z=\frac{\frac{1}{n} \sum_{i=1}^{n} S A R_{i \tau}}{\sqrt{\frac{1}{n(n-1)} \sum_{i=1}^{n}\left(S A R_{i \tau}-\frac{1}{n} \sum_{i=1}^{n} S A R_{i \tau}\right)^{2}}},
$$

where $n$ is the number of observations in the sample.

\section{Cross-sectional analysis}

To examine whether market reactions to insurers' stock prices account for insurer or typhoon characteristics, I regress the CAR on insurer or typhoon variables. I use the CAR that is estimated by the Fama-French three-factor model in the following cross-sectional analysis:

$$
C A R_{i, t y}=a+\text { InsChar }_{i, t y}+c \text { TyphChar }{ }_{t y}+e,
$$

where InsChar ${ }_{i, t y}$ is insurer $i$ 's characteristic variables on typhoon ty's landfall and TyphChar ty $_{\text {is }}$ the typhoon ty's characteristic variables, respectively.

Standard errors for the cross-sectional regression are calculated using the two-way (i.e. firm and year) cluster robust, following Petersen. ${ }^{23}$

\section{Insurer characteristic variables}

If the stock market is efficient, reactions to property-liability insurers' stock prices are also expected to depend on their other financial characteristics, such as profitability, business efficiency and growth opportunities, because these are reflected in their future net cash flow following a natural disaster. For example, Cummins and Lewis ${ }^{24}$ show that the stock prices of insurers with strong financial ratings rebounded the first week after the World Trade Center attacks, while those of insurers with weaker ratings did not. I therefore hypothesise that the market returns of individual property-liability insurers around a typhoon landfall differ according to their financial characteristics.

I examine the effect of property-liability insurers' financial characteristics, such as profitability, business efficiency and financial soundness, on market reactions to propertyliability insurer stocks. The fiscal year ends in March for all Japanese insurance companies. I run the regressions on the financial data in the previous fiscal year because all typhoons in the sample made landfall in Japan between May and November. The independent variables adopted as proxies for insurer characteristics are as follows.

The variable Dependence on Fire Insurance is defined as an insurer's net premiums written for fire insurance divided by its total net premiums written. As Table 3 shows, fire

\footnotetext{
22 Boehmer et al. (1991).

${ }^{23}$ Petersen (2009).

${ }^{24}$ Cummins and Lewis (2003).
} 
insurance claim payments account for more than 90 per cent of total typhoon damage claims. If a typhoon causes serious damage, a property-liability insurer whose net fire insurance premium income accounts for a larger proportion of total net premium income will be expected to pay more insurance claims. On the other hand, it is possible for such propertyliability insurers to gain more from increasing demand for fire insurance coverage and to increase long-run profitability. Therefore, the predicted sign of Dependence on Fire Insurance is either positive or negative.

The variable $R O E$ is defined as an insurer's net income divided by total equity. Because an insurer with high return on equity has high profitability, the predicted sign of this variable is expected to be positive.

The variable Reinsurance is defined as an insurer's reinsurance ceded divided by gross premiums written. This ratio represents the degree of reinsurance that an insurer ceded from direct insurance, such that, if this variable is high, a large part of insurance claims paid will be offset by reinsurance claims received from reinsurers, even if a natural disaster causes serious damage. Therefore, the predicted sign of this variable is expected to be positive.

The variable Capital Buffer is defined as the sum of an insurer's equity capital and catastrophic loss reserve, which is then divided by total assets. Catastrophic loss reserve is the amount that must be set aside for a tremendous insurance claim payment due to a catastrophe and is accounted for in the liabilities section of the insurer's balance sheet. This reserve is part of a uniquely Japanese accounting system and the International Financial Reporting Standards do not allow it to be considered liability because it does not satisfy the concept of liabilities. Hence, the catastrophic loss reserve is characterised more as capital than as liability. I expect that the predicted sign of this variable is positive because a higher capital buffer reduces default risk.

The variable Solvency Margin is defined as an insurer's solvency margin. Insurers operating in Japan are required to disclose this indicator since the fiscal year-end of 1998. The variable Lowrating is a dummy that equals zero if an insurer's credit rating is A+ or better and one otherwise, according to Cummins and Lewis. ${ }^{24}$ Also, the credit rating data of all property-liability insurers have only been available since 1997, following the deregulation of the Japanese insurance market with the 1996 full-fledged amendment of the Insurance Business Act. Because both solvency margin and credit ratings represent financial soundness, the predicted signs of Solvency Margin and Lowrating are expected to be positive and negative, respectively.

The variable Loss Ratio is defined as the sum of an insurer's net claims paid and loss adjustment expenses, which is then divided by total net premiums written by the insurer. ${ }^{25}$ The term Expense Ratio is defined as the sum of an insurer's agency commissions and brokerage, operating, and general administrative expenses, which is then divided by total net premiums written on the insurer. Because both Loss Ratio and Expense Ratio are indices of profitability (or x-efficiency), the predicted signs of both variables are negative.

25 The loss ratio is typically calculated as the sum of losses incurred and loss adjustment expenses, which is then divided by net premiums earned. However, because Japanese property-liability insurers do not disclose these items in their financial statements or annual reports, net claims paid and net premiums written are used here. 
Finally, I adopt $\ln$ (Assets), the natural logarithm of an insurer's total assets. I expect the predicted sign to be positive because large companies generally have low default risk.

\section{Typhoon characteristic variables}

This section examines the effects of various typhoons' characteristics on market reactions to property-liability insurer stocks. Shelor et al. ${ }^{6}$ and Lamb ${ }^{26}$ suggest that insurers with more exposure in the affected region experience larger stock price declines.

Unlike earthquakes and tornados, typhoons and hurricanes generally have a fairly lengthy time window in which information is distributed to the public about their location, landfall times, size and so on. It is expected that a typhoon identified and classified days prior to landfall will have a much larger impact on stock prices than a typhoon with a short developmental period. This paper also investigates this information to strengthen the argument for or against the impact of typhoons on stock price.

I examine the effects of typhoon characteristics such as scale, time proximity, geographical effects and economic impact on market reactions to property-liability insurer stocks. The independent variables used to proxy for typhoon characteristics are as follows.

I adopt three measures to represent typhoon scales; the terms $\ln (\mathrm{hPa}), \ln (\mathrm{ms})$ and $\ln (\mathrm{mm})$ are the natural logarithms of the highest atmospheric pressure (in hectopascals), maximum wind speed (in metres per second) and maximum rainfall (in millimetres per hour) of a typhoon, respectively. Note that the lower $\ln (\mathrm{hPa})$ is or the higher $\ln (\mathrm{ms})$ or $\ln (\mathrm{mm})$ is, the stronger the typhoon is.

If the total amount of insurance claims depends on a typhoon's scale, a stronger typhoon is expected to have a more negative impact on the stock prices of property-liability insurers. On the other hand, a strong typhoon may make headlines and stimulate people to increase demand for insurance coverage. If so, market reactions to property-liability insurer stocks around a strong typhoon will be positive. Hence, the predicted signs of $\ln (h P a), \ln (m s)$ and $\ln$ $(\mathrm{mm})$ are either positive or negative, respectively.

The variable Days since Previous Typhoon is the natural logarithm of the number of days between the date of a typhoon's landfall and the date of the previous typhoon landfall. This variable represents the time proximity of one typhoon's landfall to another's. In other words, it measures the impact of a typhoon landfall from a different event (the previous typhoon landfall). If there is a long interval between a typhoon's landfall and the previous one, news of the landfall may take the stock market by surprise. If so, the longer the interval, the stronger the market reaction to property-liability insurers around the typhoon may be. Conversely, if there is a short interval between a typhoon's landfall and the previous one, the economic damages from the typhoon landfall could increase because the previous typhoon loosened the ground.

The variable Hours between Occurrence and Landfall is the natural logarithm of the number of hours between the time a tropical cyclone was identified and classified as a typhoon and the time it made landfall in Japan. A typhoon identified and classified several days prior to landfall is expected to have a much larger impact on stock prices than a typhoon with a short development period.

\footnotetext{
${ }^{26}$ Lamb $(1995,1998)$.
} 
The variable Hours between Landfall and End is the natural logarithm of the number of hours between the time a typhoon made landfall in Japan and the time it petered out into an extratropical or tropical cyclone. In other words, this variable represents the number of hours during which a typhoon caused damage in Japan. If this variable is high, the amount of damage can increase; hence the predicted sign is negative.

As discussed in the section "Overview of typhoons", it is possible for a typhoon that makes landfall in Japan to pass through all regions-Hokkaido, Tohoku, Kanto, Chubu, Kinki, Chugoku, Shikoku and Kyushu—with almost the same probability. To examine a geographical effect, I adopt the variable Number of Landing Regions, defined as the number of regions through which a typhoon passed. Because it represents the extent of the damage range, the predicted sign is negative.

Finally, a typhoon with no significant economic damages will not have a negative impact on property-liability insurers' stock prices. Kisyonenkan reports information on damages caused by each typhoon. The term $\ln$ (Physical Damage) is the natural logarithm of the sum of the number of houses fully or half destroyed or washed away, the number of the houses partially destroyed, and the number of the houses inundated above or below ground level due to the typhoon. Because household fire insurance in Japan covers losses caused by typhoons, this variable is a proxy of the amount of insurance claims. Hence, the predicted sign is negative.

\section{Empirical results}

\section{Event study results}

The results of the event study are shown in Table 5 and Figure 2. Panels A and B of Table 5 present the average daily abnormal returns and the SAR $z$-scores from the market model (Eq. (2)) and the Fama-French three-factor model (Eq. (3)), respectively.

Table 5 shows that typhoon landfalls have a significant positive impact on the abnormal stock returns of property-liability insurers. In the JMA criteria, the CARs from 5 to 2 days before typhoon landfalls, $\mathrm{CAR}(-5,-2)$, are 0.47 and 0.58 per cent for the market and FamaFrench three-factor models, respectively, and both are positive at the 1 per cent level of significance. Furthermore, the CARs from 2 to 20 days after typhoon landfalls, $\operatorname{CAR}(2,20)$, are 0.95 and 1.16 per cent for the market and Fama-French three-factor models, respectively, and both are also positive at the 1 per cent level of significance. On the other hand, the CARs from a day before to a day after typhoon landfalls, $\operatorname{CAR}(-1,1)$, are slightly negative but not statistically significant.

As discussed in the section "Overview of typhoons", there is a difference in the WMO and JMA classifications of typhoons. Table 5 also shows the average daily abnormal returns from the market and Fama-French three-factor models, respectively, for tropical storms (TS), severe tropical storms (STS) and typhoons (TY), based on the WMO criteria. The CARs from 5 to 2 days before typhoon landfalls, CAR $(-5,-2)$, are 0.28 and 0.42 per cent for the market and Fama-French three-factor models, and those from 2 to 20 days after typhoon landfalls, $\operatorname{CAR}(2,20)$, are 1.34 and 1.47 per cent, respectively. Therefore, market reactions before and after typhoon landfalls are significantly positive, except for $\operatorname{CAR}(-5,-2)$ for the market model, even if the sample is confined to the WMO criteria. 
Table 5 Daily average abnormal returns using the market model and the Fama-French three-factor model

\begin{tabular}{|c|c|c|c|c|c|c|c|c|}
\hline \multirow{3}{*}{ Day } & \multirow{2}{*}{\multicolumn{2}{|c|}{$\begin{array}{c}\text { JMA criteria } \\
\text { Typhoon }(T Y) \\
(N=93)\end{array}$}} & \multicolumn{6}{|c|}{ WMO criteria } \\
\hline & & & \multicolumn{2}{|c|}{$\begin{array}{l}\text { Tropical storm }(T S) \\
\qquad(N=23)\end{array}$} & \multicolumn{2}{|c|}{$\begin{array}{l}\text { Severe tropical storm (STS) } \\
\qquad(N=34)\end{array}$} & \multicolumn{2}{|c|}{$\begin{array}{l}\text { Typhoon }(T Y) \\
\quad(N=36)\end{array}$} \\
\hline & $A A R(\%)$ & z-value & $A A R(\%)$ & z-value & $A A R(\%)$ & z-value & $A A R(\%)$ & z-value \\
\hline \multicolumn{9}{|c|}{ Panel A: Market model } \\
\hline$t=-5$ & 0.14 & $1.98 * *$ & 0.17 & 1.55 & -0.05 & -0.84 & 0.29 & $2.96 * * *$ \\
\hline$t=-4$ & 0.10 & $1.79 *$ & 0.14 & 1.20 & 0.22 & $2.18 * *$ & -0.05 & -0.17 \\
\hline$t=-3$ & 0.25 & $4.30 * * *$ & 0.08 & 1.38 & 0.37 & $3.81 * * *$ & 0.23 & $2.24 * *$ \\
\hline$t=-2$ & -0.01 & -0.54 & 0.00 & 0.15 & 0.18 & $1.87 *$ & -0.20 & $-2.73 * * *$ \\
\hline$t=-1$ & 0.03 & -0.15 & -0.01 & -0.48 & 0.14 & 0.79 & -0.05 & -0.55 \\
\hline$t=-0$ & -0.05 & -0.53 & -0.11 & -0.74 & 0.12 & 1.31 & -0.18 & -1.53 \\
\hline$t=1$ & -0.10 & $-1.79 *$ & -0.23 & $-2.01 * *$ & -0.29 & $-3.40 * * *$ & 0.16 & 1.50 \\
\hline$t=2$ & 0.01 & 0.52 & 0.23 & $2.00 * *$ & 0.09 & 1.27 & -0.21 & -1.53 \\
\hline$t=3$ & 0.19 & $2.65 * * *$ & -0.13 & $-1.79 *$ & 0.25 & $2.06 * *$ & 0.32 & $3.00 * * *$ \\
\hline$t=4$ & 0.17 & $2.88 * * *$ & 0.15 & $1.77^{*}$ & 0.08 & 0.37 & 0.26 & $3.03 * * *$ \\
\hline$t=5$ & 0.02 & 0.22 & 0.05 & 0.10 & -0.04 & -0.88 & 0.06 & 0.95 \\
\hline$t=6$ & 0.00 & -0.14 & -0.36 & $-3.03 * * *$ & -0.05 & -0.70 & 0.26 & $2.16^{* *}$ \\
\hline$t=7$ & -0.16 & $-2.31 * *$ & -0.04 & 0.10 & -0.19 & $-1.93^{*}$ & -0.21 & $-2.12 * *$ \\
\hline$t=8$ & 0.07 & 0.89 & 0.16 & 1.23 & -0.04 & -0.42 & 0.13 & 0.81 \\
\hline$t=9$ & 0.16 & $2.02 * *$ & 0.18 & $1.68 *$ & 0.11 & 0.33 & 0.19 & 1.49 \\
\hline$t=10$ & -0.08 & -1.05 & 0.02 & 0.22 & -0.25 & $-2.65 * * *$ & 0.03 & 0.59 \\
\hline$t=11$ & 0.04 & 1.21 & 0.26 & $2.88 * * *$ & -0.04 & -0.20 & 0.00 & 0.01 \\
\hline$t=12$ & 0.17 & $3.38 * * *$ & 0.46 & $3.72 * * *$ & 0.05 & 0.66 & 0.10 & $1.66^{*}$ \\
\hline$t=13$ & 0.01 & -0.11 & 0.33 & $2.10^{* *}$ & -0.30 & $-3.17 * * *$ & 0.10 & 1.08 \\
\hline$t=14$ & -0.13 & $-3.09 * * *$ & -0.37 & $-3.56^{* * *}$ & 0.00 & -0.69 & -0.10 & $-1.80^{*}$ \\
\hline$t=15$ & -0.06 & -0.68 & -0.22 & $-1.88^{*}$ & 0.00 & 0.69 & -0.01 & -0.44 \\
\hline$t=16$ & 0.09 & 1.61 & 0.09 & 1.11 & -0.05 & -0.58 & 0.23 & $1.92^{*}$ \\
\hline$t=17$ & 0.11 & $2.06 * *$ & 0.00 & 0.20 & 0.24 & $2.76^{* * *}$ & 0.04 & 0.47 \\
\hline$t=18$ & 0.07 & 1.31 & 0.53 & $3.55^{* * * *}$ & -0.13 & $-1.77 *$ & -0.03 & -0.02 \\
\hline$t=19$ & 0.15 & 0.75 & 0.14 & 0.60 & 0.12 & 0.32 & 0.17 & 0.41 \\
\hline$t=20$ & 0.14 & 1.08 & -0.03 & 0.13 & 0.36 & $2.35^{* *}$ & 0.03 & -0.74 \\
\hline $\operatorname{CAR}(-5,-2)$ & 0.47 & $4.28 * * *$ & 0.40 & $2.64 * * *$ & 0.73 & $3.82 * * *$ & 0.28 & 1.40 \\
\hline $\operatorname{CAR}(-1,1)$ & -0.12 & -1.50 & -0.35 & $-2.00 * *$ & -0.02 & -0.84 & -0.07 & -0.25 \\
\hline CAR $(2,20)$ & 0.95 & $3.76^{* * *}$ & 1.45 & $4.19 * * *$ & 0.20 & -0.28 & 1.34 & $2.73 * * *$ \\
\hline
\end{tabular}

Note: The symbols $*, * *$ and $* * *$ denote statistical significance at the 10,5 and 1 per cent levels, respectively.

Figure 2 plots the CARs during the event period, using two benchmarks and two criteria. As shown, property-liability insurers' stock prices increase until just before a typhoon landfall, drop once on the landfall day, but then gradually increase again. 
Takashi Yamasaki

Table 5 (continued)

\begin{tabular}{|c|c|c|c|c|c|c|c|c|}
\hline \multirow{3}{*}{ Day } & \multirow{2}{*}{\multicolumn{2}{|c|}{$\begin{array}{c}\text { JMA criteria } \\
\text { Typhoon }(T Y) \\
(N=93)\end{array}$}} & \multicolumn{6}{|c|}{ WMO criteria } \\
\hline & & & $\begin{array}{r}\text { Tropical } \\
(N\end{array}$ & $\begin{array}{l}\text { orm }(T S) \\
3)\end{array}$ & Severe trop & torm (STS) & $\begin{array}{r}\text { Typho } \\
(N=\end{array}$ & $\begin{array}{l}n(T Y) \\
36)\end{array}$ \\
\hline & $A A R(\%)$ & z-value & $A A R(\%)$ & z-value & $A A R(\%)$ & z-value & $A A R(\%)$ & z-value \\
\hline
\end{tabular}

Panel B: Fama-French three-factor model

\begin{tabular}{|c|c|c|c|c|c|c|c|c|}
\hline$t=-5$ & 0.14 & $2.16^{* *}$ & 0.13 & 1.09 & 0.07 & 0.41 & 0.22 & $2.22 * *$ \\
\hline$t=-4$ & 0.14 & $2.67 * * *$ & 0.20 & $1.77 *$ & 0.26 & $2.69 * * *$ & -0.01 & 0.41 \\
\hline$t=-3$ & 0.30 & $5.05 * * *$ & 0.14 & $1.93 *$ & 0.33 & $3.62 * * *$ & 0.36 & $3.15^{* * *}$ \\
\hline$t=-2$ & 0.00 & -0.45 & -0.01 & -0.03 & 0.16 & 1.57 & -0.14 & $-2.19 * *$ \\
\hline$t=-1$ & 0.06 & 0.39 & 0.03 & -0.06 & 0.16 & 0.89 & -0.02 & -0.09 \\
\hline$t=-0$ & -0.06 & -0.67 & -0.16 & -1.17 & 0.18 & $1.97 * *$ & -0.24 & $-2.18 * *$ \\
\hline$t=1$ & -0.05 & -0.95 & -0.09 & -0.92 & -0.16 & $-2.06 * *$ & 0.06 & 1.04 \\
\hline$t=2$ & 0.10 & $1.83^{*}$ & 0.17 & 1.46 & 0.22 & $2.43 * *$ & -0.06 & -0.41 \\
\hline$t=3$ & 0.25 & $3.58 * * *$ & -0.08 & -1.25 & 0.33 & $2.58 * * *$ & 0.37 & $3.64 * * *$ \\
\hline$t=4$ & 0.14 & $2.65 * * *$ & 0.19 & $2.23 * *$ & 0.04 & 0.29 & 0.21 & $2.51 * *$ \\
\hline$t=5$ & 0.11 & $1.67 *$ & 0.13 & 0.93 & 0.00 & -0.29 & 0.20 & $2.13 * *$ \\
\hline$t=6$ & 0.00 & -0.06 & -0.32 & $-2.69 * * *$ & -0.12 & -1.27 & 0.31 & $2.74 * * *$ \\
\hline$t=7$ & -0.10 & -1.62 & -0.08 & -0.15 & -0.16 & $-1.78 *$ & -0.08 & -1.02 \\
\hline$t=8$ & 0.06 & 0.88 & 0.18 & 1.32 & -0.08 & -0.67 & 0.13 & 0.96 \\
\hline$t=9$ & 0.16 & $2.26 * *$ & 0.20 & $1.83^{*}$ & 0.13 & 0.80 & 0.16 & 1.41 \\
\hline$t=10$ & -0.07 & -1.01 & -0.01 & -0.21 & -0.20 & $-2.36 * *$ & 0.02 & 0.65 \\
\hline$t=11$ & 0.06 & 1.31 & 0.28 & $3.02 * * *$ & -0.05 & -0.36 & 0.03 & 0.26 \\
\hline$t=12$ & 0.15 & $2.96 * * *$ & 0.47 & $3.90 * * *$ & 0.06 & 0.64 & 0.03 & 0.94 \\
\hline$t=13$ & -0.03 & -0.71 & 0.25 & 1.39 & -0.28 & $-3.07 * * *$ & 0.03 & 0.58 \\
\hline$t=14$ & -0.13 & $-2.95 * * *$ & -0.32 & $-3.01 * * *$ & 0.03 & -0.21 & -0.17 & $-2.30 * *$ \\
\hline$t=15$ & -0.06 & -0.53 & -0.20 & -1.58 & 0.02 & 0.95 & -0.06 & -0.59 \\
\hline$t=16$ & 0.09 & 1.64 & 0.15 & 1.61 & -0.07 & -0.75 & 0.20 & $1.73 *$ \\
\hline$t=17$ & 0.16 & $3.09 * * *$ & 0.09 & 0.85 & 0.23 & $2.71 * * *$ & 0.13 & 1.63 \\
\hline$t=18$ & 0.04 & 0.99 & 0.57 & $3.71 * * *$ & -0.16 & $-1.78 *$ & -0.10 & -0.62 \\
\hline$t=19$ & 0.12 & 0.60 & 0.15 & 0.67 & 0.12 & 0.38 & 0.11 & 0.09 \\
\hline$t=20$ & 0.12 & 0.78 & -0.02 & 0.14 & 0.33 & $2.13 * *$ & 0.01 & -0.93 \\
\hline $\operatorname{CAR}(-5,-2)$ & 0.58 & $5.23 * * *$ & 0.45 & $2.76^{* * * *}$ & 0.83 & $4.35 * * *$ & 0.42 & $2.21 * *$ \\
\hline $\mathrm{CAR}(-1,1)$ & -0.06 & -0.82 & -0.21 & -1.37 & 0.18 & 0.51 & -0.19 & -0.84 \\
\hline $\operatorname{CAR}(2,20)$ & 1.16 & $5.04 * * *$ & 1.80 & $5.05^{* * *} *$ & 0.40 & 0.43 & 1.47 & $3.53 * * *$ \\
\hline
\end{tabular}

Note: The symbols $*, * *$ and $* * *$ denote statistical significance at the 10,5 and 1 per cent levels, respectively.

To conclude, these results show that property-liability insurers tend to perform abnormally well around typhoon landfalls in this period. This implies that property-liability insurers, on average, benefit from typhoon landfalls because of subsequent increased consumer or institutional demand. 


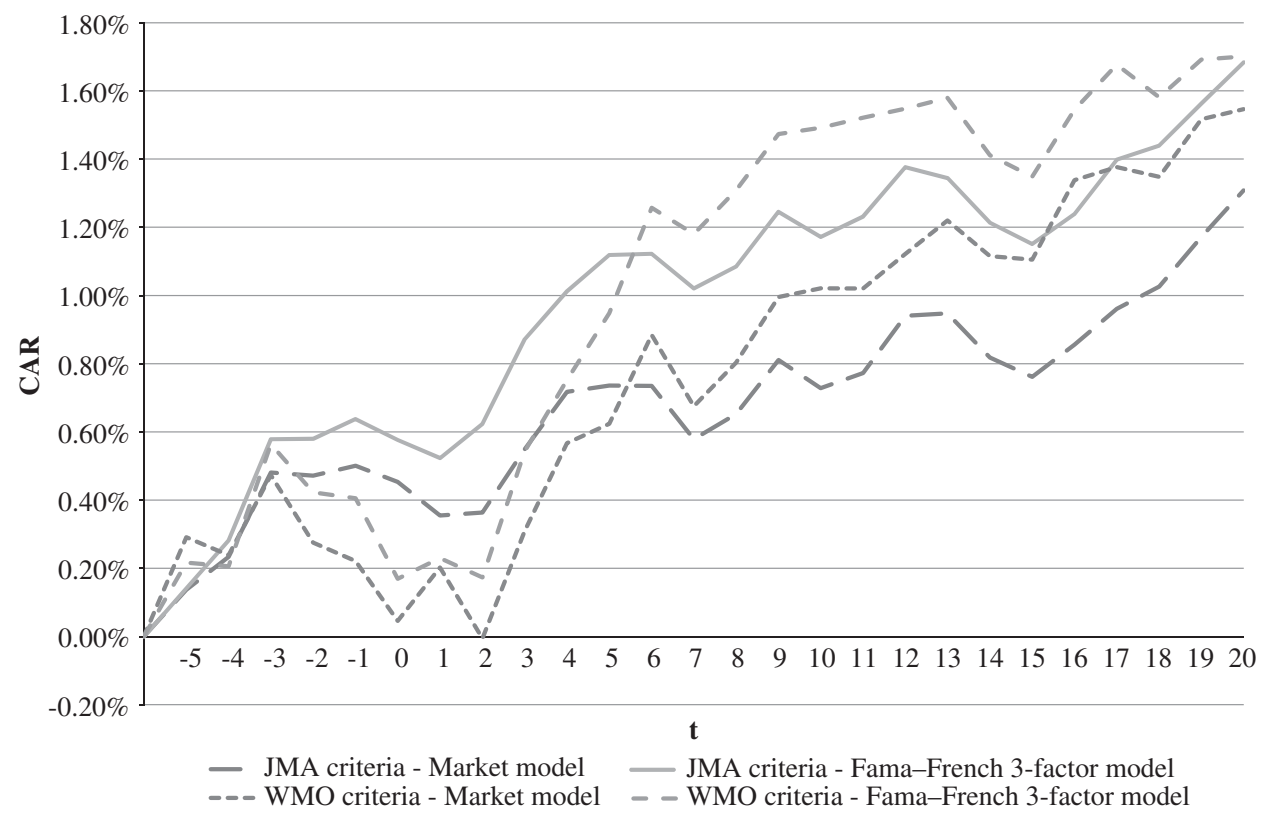

Figure 2. CARs, using two benchmarks around typhoon landfalls.

\section{Cross-sectional analysis results}

As discussed in the section "Cross-sectional analysis", I investigate whether the market reactions to insurers' stock prices account for insurer or typhoon characteristics. Table 6 shows the results of the cross-sectional regression analyses.

\section{Full-sample results}

Models (1) to (3) of Panel A of Table 6 show the results of cross-sectional regression analyses for the full event period (i.e. CAR $(-5,20)$ for the full-sample period (i.e. 1979-2013)).

First, considering the characteristics of property-liability insurers, Dependence on Fire Insurance is statistically positive. For example, the coefficient of model (3) is 0.239 and statistically significant at the 1 per cent level. This implies that a property-liability insurer will gain more from increasing demand for fire insurance coverage and increase long-run profitability.

In addition, Expense Ratio is negative, and especially its coefficient in model (3) is statistically significant at the 5 per cent level. This finding also supports the hypothesis that the stock price of an insurer with low x-efficiency reacts more negatively around a typhoon landfall.

On the other hand, Capital Buffer is negative. This result seems to be inconsistent with the hypothesis that the stock price of an insurer with less capital buffer reacts more negatively around a typhoon landfall.

The variables Reinsurance, Loss Ratio and $\ln$ (Assets) are positive, negative and positive, respectively. Their signs are consistent with the prediction, but these are not statistically significant. 
Takashi Yamasaki

Table 6 Cross-sectional regression results

\begin{tabular}{|c|c|c|c|c|c|c|c|}
\hline \multicolumn{8}{|c|}{ Panel A: Full event period } \\
\hline & \multirow{2}{*}{$\begin{array}{l}\text { Predicted } \\
\text { sign }\end{array}$} & $\begin{array}{c}(1) \\
1979-2013\end{array}$ & $\begin{array}{c}(2) \\
1979-2013\end{array}$ & $\begin{array}{c}(3) \\
1979-2013\end{array}$ & $\begin{array}{c}(4) \\
2004-2013\end{array}$ & $\begin{array}{c}(5) \\
2004-2013\end{array}$ & $\begin{array}{c}(6) \\
2004-2013\end{array}$ \\
\hline & & \multicolumn{6}{|c|}{$C A R(-5,20)$} \\
\hline \multirow{2}{*}{$\begin{array}{l}\text { Dependence on fire } \\
\text { insurance }\end{array}$} & \pm & $0.192 * * *$ & & $0.239 * * *$ & $0.335 * * *$ & $0.246^{* *}$ & 0.430 \\
\hline & & (10.09) & & $(22.01)$ & (4.64) & $(2.34)$ & $(1.56)$ \\
\hline \multirow[t]{2}{*}{ ROE } & + & $-0.321 * *$ & & $-0.437 * * *$ & 0.304 & 0.326 & 0.395 \\
\hline & & $(-2.36)$ & & $(-4.96)$ & $(1.16)$ & $(1.27)$ & $(1.51)$ \\
\hline \multirow[t]{2}{*}{ Reinsurance } & + & 0.0483 & & 0.166 & 0.169 & 0.369 & -0.159 \\
\hline & & $(0.45)$ & & $(1.53)$ & $(0.46)$ & $(0.84)$ & $(-0.42)$ \\
\hline \multirow[t]{2}{*}{ Capital buffer } & + & -0.140 & & $-0.169 * *$ & & $0.461 * * *$ & $0.612 * * *$ \\
\hline & & $(-1.59)$ & & $(-2.01)$ & & $(3.37)$ & (3.04) \\
\hline \multirow[t]{2}{*}{ Solvency margin } & + & & & & -0.00392 & $-0.0164 * *$ & $-0.0233^{* *}$ \\
\hline & & & & & $(-0.70)$ & $(-2.61)$ & $(-2.62)$ \\
\hline \multirow[t]{2}{*}{ Lowrating } & - & & & & $-0.0221 * * *$ & $-0.0245 * *$ & $-0.0308^{* * * *}$ \\
\hline & & & & & $(-2.92)$ & $(-2.34)$ & $(-10.67)$ \\
\hline \multirow[t]{2}{*}{ Loss ratio } & - & -0.199 & & -0.259 & $0.218 * *$ & 0.129 & -0.0407 \\
\hline & & $(-0.97)$ & & $(-1.27)$ & $(2.08)$ & (1.37) & $(-0.20)$ \\
\hline \multirow[t]{2}{*}{ Expense ratio } & - & -0.124 & & $-0.233^{* *}$ & $-0.293 *$ & $-0.213^{*}$ & $-0.353 * * *$ \\
\hline & & $(-1.11)$ & & $(-2.17)$ & $(-1.81)$ & $(-1.80)$ & $(-3.01)$ \\
\hline \multirow[t]{2}{*}{$\ln$ (Assets) } & + & 0.00265 & & 0.00770 & -0.00789 & -0.00610 & 0.00524 \\
\hline & & $(0.43)$ & & $(1.00)$ & $(-1.27)$ & $(-0.88)$ & $(1.25)$ \\
\hline \multirow[t]{2}{*}{$\ln (\mathrm{hPa})$} & \pm & & -0.469 & -0.579 & & & $-1.029 * *$ \\
\hline & & & $(-1.42)$ & $(-1.45)$ & & & $(-2.14)$ \\
\hline \multirow[t]{2}{*}{$\ln (\mathrm{ms})$} & \pm & & 0.00690 & 0.0266 & & & 0.0584 \\
\hline & & & $(0.27)$ & $(1.17)$ & & & $(1.33)$ \\
\hline \multirow[t]{2}{*}{$\ln (\mathrm{mm})$} & \pm & & $0.0338^{*}$ & $0.0546^{* * *}$ & & & 0.0206 \\
\hline & & & $(1.81)$ & $(3.27)$ & & & $(0.72)$ \\
\hline \multirow{2}{*}{$\begin{array}{l}\text { Days since previous } \\
\text { typhoon }\end{array}$} & \pm & & $-0.00711^{* * *}$ & $-0.00674^{* * *}$ & & & -0.00356 \\
\hline & & & $(-2.80)$ & $(-2.98)$ & & & $(-0.85)$ \\
\hline \multirow{2}{*}{$\begin{array}{l}\text { Hours between } \\
\text { occurrence and landfall }\end{array}$} & \pm & & $-0.0171^{* *}$ & $-0.0205 * * *$ & & & $-0.0376^{*}$ \\
\hline & & & $(-2.32)$ & $(-2.75)$ & & & $(-1.89)$ \\
\hline \multirow{2}{*}{$\begin{array}{l}\text { Hours between landfall } \\
\text { and end }\end{array}$} & - & & -0.0128 & $-0.0170 * * *$ & & & -0.00419 \\
\hline & & & $(-1.60)$ & $(-2.67)$ & & & $(-0.52)$ \\
\hline \multirow{2}{*}{$\begin{array}{l}\text { Number of landing } \\
\text { regions }\end{array}$} & - & & 0.00536 & 0.00276 & & & 0.0152 \\
\hline & & & $(1.14)$ & $(0.51)$ & & & $(1.24)$ \\
\hline \multirow[t]{2}{*}{ ln(Physical damage) } & - & & $-0.00786^{* * *}$ & $-0.0101 * * *$ & & & $-0.0164 * * *$ \\
\hline & & & $(-2.80)$ & $(-4.02)$ & & & $(-3.72)$ \\
\hline \multirow[t]{2}{*}{ Constant } & & 0.143 & 3.215 & 3.942 & 0.0648 & 0.0501 & $7.181 * *$ \\
\hline & & $(1.40)$ & $(1.39)$ & $(1.39)$ & $(0.96)$ & $(0.63)$ & $(2.30)$ \\
\hline$N$ & & 1,029 & 906 & 903 & 173 & 173 & 113 \\
\hline Adj. $R^{2}$ & & 0.027 & 0.049 & 0.084 & 0.001 & 0.016 & 0.068 \\
\hline
\end{tabular}

Note: The symbols $*, * *$ and $* * *$ denote statistical significance at the 10,5 and 1 per cent levels, respectively. The $t$-statistics, reported in parentheses, are based on two-way cluster-robust standard errors, following Petersen (2009). 
The Geneva Papers on Risk and Insurance-Issues and Practice

450

Table 6 (continued)

\begin{tabular}{|c|c|c|c|c|c|c|c|}
\hline \multicolumn{8}{|c|}{ Panel B: Pre-typhoon, typhoon and post-typhoon landfall } \\
\hline & \multirow{2}{*}{$\begin{array}{l}\text { Predicted } \\
\text { sign }\end{array}$} & $\begin{array}{c}\text { (1) } \\
1979-2013\end{array}$ & $\begin{array}{c}(2) \\
2004-2013\end{array}$ & $\begin{array}{c}\text { (3) } \\
1979-2013\end{array}$ & $\begin{array}{c}(4) \\
2004-2013\end{array}$ & $\begin{array}{c}(5) \\
1979-2013\end{array}$ & $\begin{array}{c}(6) \\
2004-2013\end{array}$ \\
\hline & & \multicolumn{2}{|c|}{$C A R(-5,-2)$} & \multicolumn{2}{|c|}{$\operatorname{CAR}(-1,1)$} & \multicolumn{2}{|c|}{$\operatorname{CAR}(2,20)$} \\
\hline $\begin{array}{l}\text { Dependence on fire } \\
\text { insurance }\end{array}$ & \pm & $\begin{array}{l}0.0705 \\
(1.39)\end{array}$ & $\begin{array}{l}0.0255 \\
(0.31)\end{array}$ & $\begin{array}{l}0.0536 * * * \\
(3.47)\end{array}$ & $\begin{array}{c}0.106 \\
(1.00)\end{array}$ & $\begin{array}{l}0.129 * * * \\
(2.95)\end{array}$ & $\begin{array}{r}0.299 \\
(1.28)\end{array}$ \\
\hline ROE & + & $\begin{array}{l}-0.0604^{*} \\
(-1.70)\end{array}$ & $\begin{array}{l}-0.0246 \\
(-0.50)\end{array}$ & $\begin{array}{l}-0.0477 \\
(-0.84)\end{array}$ & $\begin{array}{l}-0.0449 \\
(-0.53)\end{array}$ & $\begin{array}{l}-0.212 * \\
(-1.87)\end{array}$ & $\begin{array}{l}0.464 * \\
(1.84)\end{array}$ \\
\hline Reinsurance & + & $\begin{array}{l}0.137 * * \\
(2.40)\end{array}$ & $\begin{array}{l}0.278^{*} \\
(1.80)\end{array}$ & $\begin{array}{l}0.0343 \\
(0.81)\end{array}$ & $\begin{array}{l}-0.0532 \\
(-0.31)\end{array}$ & $\begin{array}{l}-0.00481 \\
(-0.04)\end{array}$ & $\begin{array}{l}-0.383 \\
(-1.54)\end{array}$ \\
\hline Capital buffer & + & $\begin{array}{l}-0.0307 \\
(-1.28)\end{array}$ & $\begin{array}{l}0.183 * * * \\
(3.74)\end{array}$ & $\begin{array}{l}-0.0325 \\
(-1.10)\end{array}$ & $\begin{array}{l}0.105 * * * \\
(5.54)\end{array}$ & $\begin{array}{l}-0.120 * * \\
(-2.03)\end{array}$ & $\begin{array}{l}0.324 * \\
(1.83)\end{array}$ \\
\hline Solvency margin & + & & $\begin{array}{l}-0.00845^{* * *} \\
(-4.52)\end{array}$ & & $\begin{array}{l}-0.00412 \\
(-1.67)\end{array}$ & & $\begin{array}{l}-0.0107 * \\
(-1.77)\end{array}$ \\
\hline Lowrating & - & & $\begin{array}{l}-0.00609 \\
(-0.87)\end{array}$ & & $\begin{array}{l}-0.00634 \\
(-1.04)\end{array}$ & & $\begin{array}{l}-0.0184 * * * \\
(-4.38)\end{array}$ \\
\hline Loss ratio & - & $\begin{array}{l}-0.0274 \\
(-0.51)\end{array}$ & $\begin{array}{l}-0.0851^{*} \\
(-1.78)\end{array}$ & $\begin{array}{l}-0.0430 \\
(-0.68)\end{array}$ & $\begin{array}{l}-0.0254 \\
(-1.02)\end{array}$ & $\begin{array}{l}-0.142 \\
(-1.10)\end{array}$ & $\begin{array}{l}0.0698 \\
(0.40)\end{array}$ \\
\hline Expense ratio & - & $\begin{array}{l}-0.0559^{*} \\
(-1.77)\end{array}$ & $\begin{array}{l}0.0777 \\
(1.39)\end{array}$ & $\begin{array}{l}-0.0351 \\
(-1.14)\end{array}$ & $\begin{array}{l}-0.0422 \\
(-1.04)\end{array}$ & $\begin{array}{l}-0.0870 \\
(-0.74)\end{array}$ & $\begin{array}{l}-0.389^{* *} \\
(-2.54)\end{array}$ \\
\hline $\ln$ (Assets) & + & $\begin{array}{l}0.00196 \\
(0.92)\end{array}$ & $\begin{array}{l}0.000702 \\
(0.26)\end{array}$ & $\begin{array}{l}0.00280^{*} \\
(1.82)\end{array}$ & $\begin{array}{l}0.000784 \\
(0.60)\end{array}$ & $\begin{array}{l}0.00465 \\
(0.88)\end{array}$ & $\begin{array}{l}0.00375 \\
(0.77)\end{array}$ \\
\hline $\ln (\mathrm{hPa})$ & \pm & $\begin{array}{l}-0.115 \\
(-0.68)\end{array}$ & $\begin{array}{l}0.0273 \\
(0.23)\end{array}$ & $\begin{array}{l}0.0853 \\
(0.89)\end{array}$ & $\begin{array}{l}-0.00844 \\
(-0.05)\end{array}$ & $\begin{array}{l}-0.508 \\
(-1.40)\end{array}$ & $\begin{array}{l}-1.048^{*} \\
(-1.73)\end{array}$ \\
\hline $\ln (\mathrm{ms})$ & \pm & $\begin{array}{l}0.00525 \\
(0.44)\end{array}$ & $\begin{array}{l}0.0168^{*} \\
(1.70)\end{array}$ & $\begin{array}{l}0.000970 \\
(0.10)\end{array}$ & $\begin{array}{l}-0.00314 \\
(-0.27)\end{array}$ & $\begin{array}{l}0.00755 \\
(0.40)\end{array}$ & $\begin{array}{l}0.0447 \\
(0.92)\end{array}$ \\
\hline $\ln (\mathrm{mm})$ & \pm & $\begin{array}{l}0.0107 * \\
(1.79)\end{array}$ & $\begin{array}{l}-0.00369 \\
(-0.36)\end{array}$ & $\begin{array}{l}0.00248 \\
(0.47)\end{array}$ & $\begin{array}{l}0.00571 \\
(0.44)\end{array}$ & $\begin{array}{l}0.0324 * * \\
(2.42)\end{array}$ & $\begin{array}{l}0.0186 \\
(0.53)\end{array}$ \\
\hline $\begin{array}{l}\text { Days since previous } \\
\text { typhoon }\end{array}$ & \pm & $\begin{array}{l}-0.000105 \\
(-0.10)\end{array}$ & $\begin{array}{l}0.000887 \\
(0.64)\end{array}$ & $\begin{array}{l}-0.00124 \\
(-0.92)\end{array}$ & $\begin{array}{l}-0.00290 \\
(-1.18)\end{array}$ & $\begin{array}{l}-0.00613 * * * \\
(-2.95)\end{array}$ & $\begin{array}{l}-0.00155 \\
(-0.30)\end{array}$ \\
\hline $\begin{array}{l}\text { Hours between } \\
\text { occurrence and landfall }\end{array}$ & \pm & $\begin{array}{l}0.00252 \\
(1.17)\end{array}$ & $\begin{array}{l}-0.0103 \\
(-0.57)\end{array}$ & $\begin{array}{l}0.00111 \\
(0.54)\end{array}$ & $\begin{array}{l}-0.00489 \\
(-0.78)\end{array}$ & $\begin{array}{l}-0.0226 * * * \\
(-3.39)\end{array}$ & $\begin{array}{l}-0.0225 \\
(-0.57)\end{array}$ \\
\hline $\begin{array}{l}\text { Hours between landfall } \\
\text { and end }\end{array}$ & - & $\begin{array}{l}-0.00567 * \\
(-1.67)\end{array}$ & $\begin{array}{l}-0.00188 \\
(-0.41)\end{array}$ & $\begin{array}{l}-0.00212 \\
(-0.88)\end{array}$ & $\begin{array}{l}-0.00141 \\
(-0.50)\end{array}$ & $\begin{array}{l}-0.00263 \\
(-0.51)\end{array}$ & $\begin{array}{l}-0.000906 \\
(-0.08)\end{array}$ \\
\hline $\begin{array}{l}\text { Number of landing } \\
\text { regions }\end{array}$ & - & $\begin{array}{l}0.00227 \\
(1.19)\end{array}$ & $\begin{array}{l}0.00189 \\
(0.54)\end{array}$ & $\begin{array}{l}-0.000752 \\
(-0.40)\end{array}$ & $\begin{array}{l}-0.000748 \\
(-0.21)\end{array}$ & $\begin{array}{l}0.00125 \\
(0.28)\end{array}$ & $\begin{array}{l}0.0140 \\
(1.28)\end{array}$ \\
\hline $\ln$ (Physical damage) & - & $\begin{array}{l}-0.00374 * * * \\
(-3.28)\end{array}$ & $\begin{array}{l}0.00294 \\
(1.02)\end{array}$ & $\begin{array}{l}-0.00146 \\
(-1.60)\end{array}$ & $\begin{array}{l}-0.00217 \\
(-0.91)\end{array}$ & $\begin{array}{l}-0.00339 * \\
(-1.83)\end{array}$ & $\begin{array}{l}-0.0172^{* * *} \\
(-3.69)\end{array}$ \\
\hline Constant & & $\begin{array}{r}0.721 \\
(0.60)\end{array}$ & $\begin{array}{l}-0.193 \\
(-0.22)\end{array}$ & $\begin{array}{l}-0.595 \\
(-0.86)\end{array}$ & $\begin{array}{c}0.122 \\
(0.11)\end{array}$ & $\begin{array}{r}3.504 \\
(1.38)\end{array}$ & $\begin{array}{l}7.252 * \\
(1.77)\end{array}$ \\
\hline $\begin{array}{l}N \\
\text { Adj. } R^{2}\end{array}$ & & $\begin{array}{l}903 \\
0.061\end{array}$ & $\begin{array}{l}113 \\
0.051\end{array}$ & $\begin{array}{l}903 \\
0.016\end{array}$ & $\begin{array}{c}113 \\
-0.057\end{array}$ & $\begin{array}{l}903 \\
0.078\end{array}$ & $\begin{array}{l}113 \\
0.038\end{array}$ \\
\hline
\end{tabular}

Note: The symbols $*, * *$ and $* * *$ denote statistical significance at the 10,5 and 1 per cent levels, respectively. The $t$ statistics, reported in parentheses, are based on two-way cluster-robust standard errors, following Petersen (2009). 
Next, I consider the characteristics of typhoons. First, the proxies for typhoon scales, that is, $\ln (\mathrm{hPa}), \ln (\mathrm{ms})$ and $\ln (\mathrm{mm})$, are negative, positive and positive, respectively. In particular, $\ln (\mathrm{mm})$ is statistically negative. Hence, these results indicate that investors' expectations of increased demands for insurance tend to increase for stronger typhoons.

The variable for time proximity, Days since Previous Typhoon, is significantly negative. This implies that a long interval since the previous typhoon leads to a market surprise, declining the stock prices of property-liability insurers. In addition, Hours between Occurrence and Landfall is also significantly negative. Taken together, it is possible that the news of a typhoon is initially negatively surprising for market participants.

Furthermore, Hours between Landfall and End is negative and, in particular, its coefficient in model (3) is statistically significant at the 1 per cent level. Therefore, we can view this variable as a proxy for the degree of typhoon damage. On the other hand, Number of Landing Regions is positive and inconsistent with the prediction but not statistically significant.

The term $\ln$ (Physical Damage) is significantly negative. This variable is a more direct proxy of the typhoon's economic impact than Hours between Landfall and End and Number of Landing Regions. The fact that the coefficient is strongly negative is consistent with the hypothesis that if catastrophic losses exceed investors' expectations of additional demands for insurance, the stock prices of property-liability insurers decline.

\section{The last 10 years' results}

Models (4) to (6) of Panel A of Table 6 show the results of cross-sectional regression analyses for $\operatorname{CAR}(-5,20)$ for the last 10 years.

According to models (5) and (6), Capital Buffer is significantly positive at the 1 per cent level. Compared with the full-sample period (models (1) and (3)), the coefficients change in the right direction. In addition, Lowrating is significantly negative at the 1 or 5 per cent level; that is, these results are consistent with the hypothesis that an insurer with a higher capital buffer or greater financial soundness is at lower default risk, so that it is evaluated relatively higher when a catastrophe happens. ${ }^{27}$

Why capital buffer and financial soundness came to work as a signal of default risk is likely due to the intensification of competition among insurers after the deregulation of the insurance industry in Japan. Japanese insurers had been protected by the so-called "convoy" system before deregulation, so that there was little chance of an insurer going bankrupt. Today, however, if an insurer becomes financially distressed, it will certainly face the risk of bankruptcy. Hence, these results imply that market participants began to evaluate the firm value of Japanese insurers according to capital buffers and financial soundness when natural disasters occur.

On the other hand, Solvency Margin does not work well for catastrophes such as typhoons. For example, the coefficient of Solvency Margin in model (6) is -0.0233 and is inconsistent with the prediction. One possible reason is due to the validity of the solvency margin. Many point out that the solvency margin does not reflect an insurer's actual solvency in Japan. For example, several Japanese life insurers failed around 2000, despite solvency

${ }^{27}$ Takao et al. (2013) show that the stock prices of Japanese insurers with a larger capital buffer rebounded after the GEJE. 
margins of over 200 per cent, which was considered safe for insurers. Indeed, the Financial Services Agency of Japan decided to strictly reassess this indicator after the 2011 fiscal year.

\section{Pre-typhoon, typhoon and post-typhoon landfall results}

Panel B of Table 6 presents the regression results for the pre-typhoon period $(\mathrm{CAR}(-5,-2)$; models (1) and (2)), the typhoon period $(\operatorname{CAR}(-1,1)$; models (3) and (4)), and the post-typhoon landfall period (CAR $(2,20)$; models (5) and (6)). By dividing the event period, I investigate the robustness of the cross-sectional analysis and the timing of the information represented by each variable reflected in property-liability insurers' stock prices around typhoon landfall.

For the full-sample period (models (1), (3) and (5)), the signs of many variables are constant among three sub-event periods. The coefficients of Reinsurance, $\ln (\mathrm{hPa})$, Hours between Occurrence and Landfall, and Number of Landing Regions are not constant, but no variable's statistical significance inverts among the event periods. The same holds for the last 10 years (models (2), (4) and (6)). Therefore, the results of the cross-sectional analysis in the sections "Full-sample results" and "The last 10 years' results" are robust.

Next, I calculate the Akaike information criterion (AIC) to investigate the adequacy of these models. For the full-sample period, the AIC value of each model is -3631.94 for model (1), -3723.59 for model (3) and -2261.72 for model (5). Therefore, model (3) (i.e. CAR $(-1,1)$ ), with the lowest AIC value, is preferred among the full-sample period models.

On the other hand, for the last 10 years, the AIC value of each model is -580.63 for model (2), -567.57 for model (4) and -342.07 for model (6). Model (2) (CAR $(-5,-2)$ ) is therefore preferred with respect to the AIC.

The fact that the preferred model has changed from that of the typhoon period $(\mathrm{CAR}(-1,1))$ to that of the pre-typhoon period $(\mathrm{CAR}(-5,-2))$ over the last 10 years implies that the timing of the information reflected in insurers' stock prices has recently sped up. One possible reason is that the development of weather forecasting technology has enabled analyses of a typhoon's impact on the Japanese economy immediately after it is spawned. In addition, the intensification of competition among insurers since the deregulation of the Japanese insurance industry may have quickened the market's response to revisions of insurers' future earnings forecasts.

\section{Conclusion}

This paper investigates how natural disasters influence the stock prices of property-liability insurance companies. Examining a series of typhoons that made landfall in Japan, I find that the stock prices of property-liability insurers, on average, increase around typhoon landfalls. This finding is consistent with the hypothesis that insurers benefit from natural disasters because of subsequent increased consumer or institutional demand, including increases in coverage and additional premium earnings.

However, the conclusion that the stock prices of property-liability insurers increase unconditionally around a natural disaster should be carefully considered. As discussed in the section "Research design", a property-liability insurer's stock price will decrease if the insurance claims from a natural disaster exceed investors' expectations of additional 
insurance demand. The cross-sectional results indicate that specific insurer or storm characteristics can moderate the increase.

Property-liability insurers' characteristics such as dependence on fire insurance and the expense ratio have an impact on their stock prices. This implies that stock market participants pay attention to these insurers' profitability and business efficiency around natural disasters. Furthermore, the result implies that market participants also pay attention to insurers' default risk since the deregulation. Japanese insurance companies had been protected by industry regulations for a long time, but, since, property-liability insurers have had to weather out natural disasters through sufficient capital buffers.

On the other hand, the results do not show that property-liability insurers' solvency margin is applicable in Japan, indicating an important suggestion for insurance regulation. Because several Japanese life insurers failed around 2000 despite solvency margins of over 200 per cent, the issue of the validity of the solvency margin of life insurers has been mainly focused in Japan. This paper reveals the same problem for Japanese property-liability insurers. It seems that stock market participants pay adequate attention to capital buffers and financial soundness indicators such as credit ratings, since the deregulation. Therefore, if solvency margins can be reflected in property-liability insurer's actual solvency, this is valuable information for stock market participants with which to conduct informed trading. It should contribute to stabilising the stock prices of healthy property-liability insurance companies around natural disasters.

Typhoon characteristics, such as scale, interval since the previous one, time to landfall, and damages, also have an impact on property-liability insurers' stock prices. The finding that residential damage has an especially negative impact on stock prices strengthens the hypothesis that property-liability insurers' stock price reactions depend on whether the insurance claims from a natural disaster exceed investors' expectations of additional insurance demand.

The results of this paper help explain why previous studies focusing on the effects of a single specific catastrophe yield contradictory results. Market reactions to property-liability insurers' stock prices around a natural disaster differ, depending on a variety of insurer and disaster characteristics. Therefore, specific catastrophic events need to be analysed more carefully, considering the impact that these factors have on property-liability insurers.

\section{Acknowledgements}

I thank Yoshihiro Asai, Fudeji Hama, Takeshi Kobayashi, Hideya Kubo, Keiichi Morita, Mariko Nakabayahi, Satoshi Nakaide, Sanae Ohno, Futoshi Okada, Mahito Okura, Yoshihiko Suzawa, Atsushi Takao, Kei Tomimura, Nobuyoshi Yamori, Noriyoshi Yanase, Yukihiro Yasuda, Takau Yoneyama, and two anonymous reviewers for their helpful comments on earlier versions of this paper. This work was supported by JSPS KAKENHI Grant Number 15K21158.

\section{References}

Aiuppa, T.A., Carney, R.J. and Krueger, T.M. (1993) 'An examination of insurance stock prices following the 1989 Loma Prieta earthquake' Journal of Insurance Issues 16(1): 1-14.

Aiuppa, T.A. and Krueger, T.M. (1995) 'Insurance stock prices following the 1994 Los Angeles earthquake', Journal of Insurance Issues 18(1): 23-35. 
Blau, B.M., Van Ness, R.A. and Wade, C. (2008) 'Capitalizing on catastrophe: Short selling insurance stocks around Hurricanes Katrina and Rita', The Journal of Risk and Insurance 75(4): 967-996.

Boehmer, E., Musumeci, J. and Poulsen, A.B. (1991) 'Event-study methodology under conditions of event-induced variance', Journal of Financial Economics 30(2): 253-272.

Cagle, J.A.B. (1996) 'Natural disasters, insurer stock prices, and market discrimination: The case of Hurricane Hugo', Journal of Insurance Issues 19(1): 53-68.

Cummins, J.D. and Lewis, C.M. (2003) 'Catastrophic events, parameter uncertainty and breakdown of implicit longterm contracting: The case of terrorism insurance', Journal of Risk and Uncertainty 26(2/3): 153-178.

Fama, E.F. and French, K.R. (1993) 'Common risk factors in the returns on stocks and bonds', Journal of Financial Economics 33(1): 3-56.

Lamb, R.P. (1995) 'An exposure-based analysis of property-liability insurer stock values around Hurricane Andrew', The Journal of Risk and Insurance 62(1): 111-123.

Lamb, R.P. (1998) 'An examination of market efficiency around hurricanes', The Financial Review 33(1): $163-172$.

Lamb, R.P. and Kennedy, W.F. (1997) 'Insurer stock prices and market efficiency around the Los Angeles Earthquake', Journal of Insurance Issues 20(1): 10-24.

Petersen, M.A. (2009) 'Estimating standard errors in finance panel data sets: Comparing approaches', The Review of Financial Studies 22(1): 435-480.

Shelor, R.M., Anderson, D.C. and Cross, M.L. (1992) 'Gaining from loss: Property-liability insurer stock values in the aftermath of the 1989 California earthquake', The Journal of Risk and Insurance 59(3): 476-488.

Sigma (2014) World Insurance in 2013, Zurich: Swiss Reinsurance Company.

Takao, A., Yoshizawa, T., Hsu, S. and Yamasaki, T. (2013) 'The effect of the Great East Japan earthquake on the stock prices of property-liability insurance companies', The Geneva Papers on Risk and Insurance-Issues and Practice 38(3): 449-468.

Yamori, N. and Kobayashi, T. (2002) 'Do Japanese insurers benefit from a catastrophic event? Market reactions to the 1995 Hanshin-Awaji earthquake', Journal of the Japanese and International Economies 16(1): 92-108.

\section{About the Author}

Takashi Yamasaki is an associate professor of finance at the Graduate School of Business Administration at Kobe University in Japan. He received his master's and $\mathrm{PhD}$ degrees in Business Administration from Kobe University. His research interests include investments, corporate finance, behavioural finance, risk management and insurance.

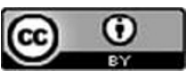

This work is licensed under a Creative Commons Attribution 3.0 Unported

License. The images or other third party material in this article are included in the article's Creative Commons license, unless indicated otherwise in the credit line; if the material is not included under the Creative Commons license, users will need to obtain permission from the license holder to reproduce the material. To view a copy of this license, visit http://creativecommons.org/licenses/by/3.0/ 